\title{
IMPROVISASI STRATEGI DAN METODE DAKWAH BAGI REMAJA
}

\author{
Sofyan Rofi \\ Dosen Program Studi Pendidikan Agama Islam Fakultas Agama Islam \\ Universitas Muhammadiyah Jember \\ Email : sofyan.rofi@unmuhjember.ac.id
}

\begin{abstract}
Abstrak
The phenomena of teenagers who always gather and socialize in certain places are a common thing in society. Teenagers tend to gather in one favourite place and make the place a 'base camp' for the group. Popular places such as cafes, wi-fi areas and others constitute a favourite place for teens to gather and socialize. A sense of comfort in that place is basically a prospect for Islamic preaching in providing religious knowledge. This condition, however, also poses a challenge for Islamic preaching requiring high level of creativity in practice. Improvisation in giving knowledge of Islam, therefore, is a necessity. Improvisation in raising religious awareness is needed so that teenagers feel comfortable in accepting Islamic values. The study adopted a qualitative approach. The participants were selected using purposive sampling comprising primary and secondary data. Primary data were data that were obtained directly from observations and interviews, while secondary data were obtained primarily from analysing some documents. The study was conducted in the sub-district area of Ambulu. The techniques for collecting data included observation, interviews, and documentation. Data analysis was conducted through reduction, data display and verification (conclusion drawing). To test the validity of the data analysis, triangulation technique was carried out. The conclusion of this study is the improvisation of preaching strategies used includes increasing teenagers' understanding by means of personal approaches, participatory approaches, and youth empowerment.
\end{abstract}

Kata Kunci : Improvisasi, Dakwah, Remaja.

\section{PENDAHULUAN}

Fenomena remaja yang selalu berkumpul dan bersosialisasi di tempattempat tertentu adalah hal yang biasa terjadi di masyarakat. Remaja cenderung berkumpul di satu tempat favoritnya dan menjadikan tempat tersebut sebagai basecamp bagi kelompoknya. Peneliti menganggap fenomena ini menarik untuk diteliti dilihat dari bagaimana remaja bisa membuat suatu tempat favorit untuk berkumpul. Kemampuan dalam mewujudkan hal itu, berpengaruh kepada loyalitas remaja untuk berdiam dan berkumpul di tempat tersebut.

Rutinitas kegiatan remaja untuk berdiam dan beraktifitas ditempat tersebut populer dengan aktifitas yang disebut dengan "nongkrong". Istilah "nongkrong" 
merupakan kegiatan yang sering dilakukan para remaja dan orang-orang yang masih masuk dalam kategori produktif. Kegiatan ini dapat dilakukan dimana saja, termasuk di kafe-kafe atau tempat berkumpul lainnya. Nongkrong bagi remaja merupakan salah satu kegiatan untuk mengisi waktu luang mereka setelah penat bekerja atau sekolah. Bagi para penyuka kegiatan nongkrong ini, mereka membutuhkan sarana dan prasarana yang memadai. Sarana dan prasarana itu berupa tempat, kenyamanan yang ditawarkan, dan juga produk yang tersedia.

Remaja merupkan periode transisi menuju kedewasaan. Seharusnya, dimasa transisi tersebut, seorang remaja berusaha mencari jati diri untuk masa depan. Tak hanya masa depan dirinya sendiri, tetapi juga masa depan bangsa. Dengan demikian, kelak, seseorang tersebut dapat menjadi pribadi yang baik dan dapat menjadi panutan umat dan bangsa.

Lalu, bagaimana jadinya jika remaja jaman sekarang yang terkenal ababil atau anak baru labil lebih sering menghabiskan waktu untuk bermain, berhura-hura dan mengisi waktu dengan hal-hal yang kurang penting dan sama sekali kurang bermanfaat? Apa jadinya bangsa kita ini ketika penerus bangsa banyak yang acuh terhadap kemajuan kualitas dirinya bahkan kualitas bangsanya?. Miris rasanya melihat remaja sekarang lebih sering kongkow-kongkow diluar, di kafe dan ditempat-tempat umum dengan berbagai macam gaya dan tingkah laku.

Berbagai macam kasus kriminal dan asusila yang terjadi di masyarakat tidak jarang membawa nama kalangan remaja di dalamnya. Stigma negatif juga tidak urung melekat dengan mudah pada individu remaja, misalkan saja kasus narkoba, seks bebas, brutalisme jalanan, dan lain sebagainya. Stigma tersebut dapat dikatakan telah menyamaratakan status moral remaja di mata khalayak belakangan ini. Kondisi tersebut tidak lepas dari aktifitas media dalam melakukan pemberitaan. Media adalah sumber informasi yang menayangkan gambaran kehidupan serta fakta-fakta tersebut kepada publik. Tujuannya adalah memberikan muatan informasi yang memiliki nilai berita yang diminati oleh khalayak. Realitas yang ditampilkan media adalah realitas yang sudah diseleksi atau realitas tangan kedua (second hand reality), sehingga dapat membentuk citra tentang lingkungan sosial berdasarkan realitas kedua yang ditampilkan media masa.

Bagi sebagian kalangan informasi yang diberikan oleh media akan dikonsumsi mentah, tanpa adanya penalaran yang lebih mendalam dan kesadaran objektifitas pada dirinya. Padahal informasi yang diberikan oleh media hanyalah potret dari sebagian kecil fenomena sosial yang ada didalam masyarakat. Hanya saja mungkin ada penegasan dan pengulangan yang dilakukan oleh media sehingga khlayak merasakan informasi yang diberikan oleh media terasa begitu kuat dan terlihat sama untuk semua subjek maupun objek pemberitaan. Pada kenyataannya tidak semua remaja memiliki kecenderungan gaya hidup negatif. Ada pula kalangan remaja yang masih menjunjung tinggi nilai moral, budaya, dan agama dalam kehidupan sehari-hari. 
Kondisi perbedaan perilaku remaja masa kini dimungkinkan karena adanya latar belakang kehidupan sosial yang berbeda. Globalisasi juga memiliki pengertian sebuah peningkatan keterkaitan dan ketergantungan antarbangsa dan antarmanusia di seluruh dunia dengan memulai perdagangan, investasi, perjalanan, budaya populer, dan bentuk interaksi yang lain sehingga batas-batas suatu negara menjadi bias. Dewasa ini dengan terjadinya perkembangan global disegala bidang kehidupan selain mengindikasikan kemajuan umat manusia disatu pihak, juga mengindikasikan kemunduran akhlak di pihak lain. Di samping itu, era informasi yang berkembang pesat pada saat ini dengan segala dampak positif dan negatifnya telah mendorong adanya pergeseran nilai di kalangan remaja.

Kemajuan kebudayaan melalui pengembangan IPTEK oleh manusia yang tidak seimbang dengan kemajuan moral akhlak, telah memunculkan gejala baru berupa krisis akhlak terutama terjadi dikalangan remaja yang memiliki kondisi jiwa yang labil, penuh gejolak dan gelombang serta emosi yang meledakledak ini cenderung mengalami peningkatan karena mudah dipengaruhi.

Sementara itu bagi mereka remaja yang memiliki tingkat keimanan dan penghargaan terhadap nilai-nilai budaya yang kuat kemungkinan besar dapat menangkal hal-hal negatif tersebut. Berdasarkan pengetahuan yang didapatkan dari pergaulan setiap hari oleh penulis kalangan remaja era masa kini cenderung lebih senang menghabiskan waktu untuk jalan-jalan di mal, bermain games, menghabiskan waktu di kafe dan lain sebagainya tanpa menyisihkan waktu untuk memenuhi kebutuhan rohaninya yaitu mendekatkan diri dengan Tuhan. Gambaran realitas yang dapat dijadikan salah satu indikasi menurunnya minat remaja akan acara dakwah adalah dengan terlihatnya kalangan dewasa dan manula sebagai golongan mayoritas dalam acaraacara keagamaan Islam seperti misalnya pengajian, khutbah, dan silaturahmi keagamaan lainnya. Walaupun pada kenyataannya tidak bisa diketahui dan diberikan penilaian penilaian secara mutlak pada keimanan setiap orang, akan tetapi hal tersebut adalah bukti konkrit dari sebuah usaha peningkatan keimanan umat Islam yang kurang mendapatkan respon yang kuat dari kalangan remaja. Solusi dakwah dengan model baru sepertinya diharapkan oleh khalayak muda.

Gerakan dakwah di era modern dan milenial saat ini harus mampu mendobrak dan melintasi batas formalitas, dengan maksud bahwa dakwah tidak hanya dilakukan di masjid, majlis ta'lim, musholla tetapi bisa di cafe, area bermain, area kongkow remaja. Fenomena ini peneliti dapati di daerah Ambulu. Figur yang dianggap sebagai panutan dan sekaligus pemilik cafe mampu memanfaatkan modal tersebut sebagai sarana dakwah dalam memberikan pengatahuan agama pada remaja. Pengunjung cafe yang mayoritas dari kalangan remaja dan usia sekolah menjadi tempat dakwah sekaligus sebgai tempat berkumpulnya para remaja tidak hanya untuk sekedar bercengkarama dengan seusianya, tetapi juga diberdayakan dalam hal pengelolaan cafe tersebut. Pengunjung kafe bambu ini kebanyakan adalah siswa 
yang sedang duduk di bangku sekolah baik SMP maupun SMA dan bahkan tak jarang pengunjung adalah mahasiswa yang sedang studi di berbagai perguruan tinggi di kabupaten Jember. Berbeda dengan kafe lainnya. Peneliti beberapa kali berkunjung di kafe tersebut dan tidak jarang peniliti bertegur sapa serta sempat berkomunikasi dengan anak-remaja disana.

Pengunjung kafe bambu kebanyakan menjadi pengunjung tetap dan bahkan sering bertambah. Setelah peneliti berkomunikasi dengan beberapa pengunjung yang merupakan remaja, mereka menjelaskan bahwa di kafe banyak mendapatkan ilmu pengetahuan dibidang keagamaan baik terkait dengan berbuat baik kepada kedua orang tua, beribadah sholat dan lainnya. Berdasrkan fakta inilah peneliti setelah berkomunikasi dengan pengunjung beranggapan bahwa pemilik kafe memiliki potensi strategis dlam dakwah khusus yang mampu merubah perilaku anak-remaja sehingga taat beragama.Rumusan masalah peneltiian ini antara lain : 1). Bagaimaan improviasi strategi dakwah pada kalangan remaja di kecamatan Ambulu?

\section{METODE PENELITIAN}

Metode penelitian yang digunakan adalah kualitatif. Alasan digunakan metode kualitatif untuk lebih mudah apabila berhubungan langsung dengan kenyataan yang tidak terkonsep sebelumnya tentang keadaan di lapangan dan data yang diperoleh dapat berkembang seiring dengan proses penelitian berlangsung. Penelitian ini dilaksanakan di wilayah Kecamatan Ambulu kabupaten Jember.

Beberapa pertimbangan yang menjadi dasar pengambilan tempat penelitian adalah posisi Kecamatan Ambulu yang merupakan daerah selatan kabupaten Jember yang mulai maju seperti halnya perkotaan dimana banyak beberapa tempat nongkrong bagi anakremaja masa kini seperti kafe, karaoke dan lain sebagainya. Adapun untuk cluster responden diambil dari remaja yang sering berkunjung di kafe.

Sumber data dalam penelitian ini dipilih secara purposive sampling, yaitu memilih anak-remaja yang dianggap mempunyai pengetahuan terhadap objek yang diteliti, sehingga mampu membuka jalan untuk meneliti lebih dalam dan lebih jauh tentang srategi dakwah Haji Muhammad Sigit Prakoso dalam meningkatkan pemahaman agama remaja . Dalam penelitian ini sumber penelitian yang digunakan adalah data primer dan data skunder. Sumber data primer yaitu data yang langsung di dapat dari hasil observasi dan wawancara. Data sekunder yaitu dokumen misalnya foto-foto proses kegiatan da'wah serta kegiatan remaja di kafe. Adapun informan primer dalam penelitian adalah pemilik kafe dan responden sekunder remaja yang sering berkunjung di kafe serta orang tua anakanak tersebut.

Teknik pengumpulan data yang digunakan meliputi observasi, wawancara, studi dokumentasi. Adapun untuk analisis data penelitian menggunakan reduksi data, data display dan verification (conclusion drawing). Utnuk pengujian keabsahan data menggunkan teknik triangulasi. 


\section{HASIL PENELITIAN DAN PEMBAHASAN}

\section{Hasil Penelitian}

Kafe yang bertempat di Ambulu terletak jalan Suyitman Ambulu, daerah tersebut sangat strategis sebab merupakan daerah kota tidak jauh dari alun-alun kota dan pasar kota Ambulu. Dengan begitu sangat mudah bagi masyarakat sekitar untuk mendatanginya. Kafe tersebut dekat dengan lembaga pendidikan SMA Negeri 1 Ambulu dan SMK Muhammadiyah 3 Ambulu. Lokasi kafe merupakan jalan menghubung dengan alun-alun dan pasar kota Ambulu serta kantor kepolisian sektor Ambulu.

Kafe didirikan diawal tahun 2010. Keberadaannya diawal sudah diniatkan untuk mendirikan kafe. Hal ini bermula dari obrolan bersama dengan masyarakat lingkungan sekitarnya maupun dirumah sehabis sholat subuh berjama'ah dimasjid. Dari situlah muncul ide mendirikan kafe. Rumah yang awalnya sebagai tempat tinggal dimanfaatkan untuk didirikan warung kopi (kafe). Mengingat halaman rumah yang sangat luas dan dirasa didaerah Ambulu belum begitu banyak tempat mengobrol maka didirikanlah tempat sederhana warung kopi (kafe) dari bahan bambu.

Tujuan dalam mendirikan kafe adalah memberikan kesempatan kepada saudara-saudara dan anak-anak tetangga yang masih sekolah dapat mencari tambahan uang saku diluar jam sekolah dan jam belajarnya serta disela-sela bekerjanya tersebut dapat disisipi dengan beberapa nasihat agar selalu dapat berbuat baik kepada kedua orang tua serta tidak lupa dengan kewajiban agama. Unsur ppemberdayaan menjadi faktor dominan dalam menggagas pendirian kafe tersebut. Seiring dengan berjalannya waktu maka banyak anak-remaja dari lingkungan lain datang ngobrol sambil minum kopi di kafe tersebut.

\section{Strategi dan Metode Dakwah dalam Meningkatkan Pemahaman Agama Remaja}

Strategi adalah pendekatan secara keseluruhan yang berkaitan dengan implementasi ide atau gagasan, perencanaan dan pelaksanaan sebuah kegiatan dalam kurun waktu tertentu. (Abdul Basit, 2013: 165). Improviasai strategi dakwah dalam meningkatkan pemahaman agama di sini adalah cara yang digunakan untuk melakukan pendekatan dan mencoba untuk memahamkan nilai-nilai keagamaan terhadap remaja. Diawal anak-remaja berkunjung di kafe bambu tersebut pemilik kafe melakukan pendekatan dengan cara menyapa dan berkenalan dengan setiap pengunjung kafe tersebut. Dengan mencoba melakukan pendekatan bergurau dan saling sapa agar dapat diterima keberadaannya ditengah-tengah kerumunan anak-remaja tersebut sambil bertanya-tanya apa permasalahanpermasalahan yang dihadapi sehingga hampir setiap malam datang dan berkunjung di kafe sampai larut malam. Maka dengan begitu anak-remaja yang sebagai pengunjung warung tersebut membuka permasalahan yang dihadapinya, disitulah peran improvisasi dakwah yang melekat pada pemilik dalam 
memberikan saran dan nasihat keagamaan kepada para pengunjung. Bagaimana jika sudah waktu sholat harus sholat terlebih dahulu, bahkan pemilik kafe menyediakan tempat sholat dan tempat berdiskusi dengan anak-remaja pengunjung kafe tersebut. Disini menunjukkan bahwa strategi yang dilakukan adalah pendekatan secara personal kepada anak-remaja tersebut.

Berawal dari situlah maka pemilik kafe bambu melakukan da'wah keagamaan terhadap anak-remaja pengunjung kafe tersebut. Isidental yang melahirkan rutinitas pada akhirnya mendorong untuk menentukan hari-hari tertentu untuk mengumpulkan anakremaja pengunjung kafe yang merupakan pelanggan tetap untuk melakukan semacam halaqoh dikediaman beliau. Materi yang disampaikan beragam baik seputar masalah-masalah kenakalan remaja sampai masalah-masalah ilmu keagamaan. Dengan berjalannya waktu tersebut ahirnya pengunjung kafe semakin banyak, bahkan tidak hanya anak-anak sekolah namun juga banyak yang sudah berkeluarga.

Dengan kegiatan-kegiatan yang dilakukan tentu membuat perubahan bagi para pengunjung yakni perubahan sikap anak-remaja tersebut. Perubahan tersebut dirasakan oleh beberapa orang tua, bahkan banyak orang tua yang bertanya-tanya bagaimana anak-anak mereka bisa berubah dengan cepat yang biasanya sulit diatur lebih mudah diatur, sulit menjalankan sholat lebih mudah menjalankan sholat. Penasaran orang tua anak-anak tersebut akhirnya menggugah orang tua menemui pemilik warung kopi atau kafe bambu. Disanalah akhirnya terjadi sharing antara orang tua dengan pemilik kafe bambu. Diantara orang tua anak yang menemui pemilik kafe tersebut merupakan salah satu pengunjung.

Dari uraian di atas, menunjukkan bahwa pemilik kafe telah mengimplementasikan fungsi dakwah. Diantara fungsi dakwah adalah; 1). Untuk menyebarkan Islam kepada manusia sebagai individu dan masyarakat sehingga mereka merasakan rahmat Islam sebagai rahmatan lil 'alamin bagi seluruh makhluk Allah. Firman Allah QS. alAnbiya: 108; "Sesungguhnya yang diwahyukan kepadaku adalah: "Bahwasanya Tuhanmu adalah Tuhan Yang Esa, maka hendaklah kamu berserah dari (kepada-Nya)". (QS.alAnbiya:108); 2). Melestarikan nilai-nilai Islam dari generasi kaum muslimin berikutnya sehingga kelangsungan ajaran Islam beserta pemeluknya dari generasi ke generasi berikutnya tidak terputus; 3). Korektif artinya meluruskan akhlak yang bengkok, mencegah kemungkaran dan mengeluarkan manusia dari kegelapan rohani. (Ali, 2004: 58-59).

Dengan demikian penulis dapat menarik kesimpulan, bahwa improviasai strategi dakwah yang dilakukan dalam menanamkan nilai-nilai keagamaan terhadap remaja lebih efektif ialah: 1). Melakukan pendekatan personal dengan anak-remaja pengunjung kafe bambu; 2). Melakukan pendekatan partisipatif yakni mengadakan aktivitas dakwah yang lebih kreatif salah satunya dengan cara dakwah mengadakan halaqoh hasil halaqoh tersebut diimplementasikan dalam kehidupan sehari-hari seperti sholat, membaca Al-qur'an (darus saat ramadhan) dan lainnya yang dapat memberikan 
pengetahuan dan pemahaman kepada remaja dan masyarakat tentang ajaran Islam. Tujuan strategi dakwah tersebut adalah agar remaja dan masyarakat di Wilayah Ambulu dan sekitarnya mengetahui dan memahami agama Islam dengan baik dan benar. Atas dasar inilah tujuan dakwah dalam arti luas adalah perubahan tingkahlaku atau sikap dan mental. Adapun tujuan dakwah menurut Ali (2004: 63-64) antara lain :

1. Untuk menegak $A d$-din, yaitu agama Allah yang benar, sehingga agama tersebut menjadi sesuai dengan ajaran Islam.

2. Untuk menyeru kepada perbuatan yang baik dan mencegah perbuatan yang munkar.

3. Untuk memahami kepada masyarakat umum tentang ajaran Islam yang dibawa oleh Nabi Muhammad saw.

4. Untuk melahirkan masyarakat yang Islami dengan berpegang dengan ajaran Islam.

Dalam melaksanakan kegiatankegiatan dakwah, jika menginginkan hasil maksimal dan tepat sasaran sesuai tujuan akhir, proses improvisasi dakwah perlu mempersiapkan rancangan sedemikian rupa seperti kegaitan pengajian dan kegiatan-kegiatan lain dari jauh hari sebelum pelaksanaan kegiatan-kegiatan di mulai. Hal ini dapat mendorong efektifitas dan efisiensi gerakan dakwah yang dilakukan.

\section{Remaja dan masyarakat} pengunjung kafe, apabila ada informasi tentang kegiatan-kegiatan yang di laksanakan ada yang ikut bisa langsung datang ke kafe tersebut. Hal ini menjadi daya tarik sendiri bagi remaja dan masyarakat yang suka akan wawasan pengetahuan agama untuk lebih memperdalam pengetahuan keagamaannya melalui kegiatan-kegitan non formal.

Kegiatan dakwah sejatinya bertujuan untuk menyebarkan ajaran agama Islam secara menyeluruh, kafe sebagai tempat berkumpu sudah merancang beberapa kegiatan untuk menyebarkan agama Islam aktivitas dakwah sebagai program pengembangan dakwah dari kegiatan-kegiatannya. Mengingat pengetahuan dan pemahaman agama zaman yang sudah semakin maju, maka aktivitas dakwah dapat digunakan sebagai alternatif dakwah. Beberapa kegiatan dakwah yang diadakan antara lain seperti pengajian remaja, kegiatan bakti sosial dan sebagainya.

Kegiatan yang diadakan mendapat respon baik oleh masyarakat sekitar maupun remaja,. Dengan diadakannya kegiatan tersebut diharapakan dapat mengetahui dan memahami keagamaan dan memperdalam. Karena bagaimanapun, kegiatan dakwah ini ditujukan untuk memenuhi dahaga spiritual akan hikmah-hikmah religi.

Para remaja dan masyarakat dapat mengambil i'tibar atau pelajaran dari kegiatan-kegiatan yang di lakukan seperti mengingatkan akan alam akhirat dimana segala amal perbuatan kita sewaktu di alam dunia akan dipertanggungjawabkan di hadapan Allah SWT, selain itu bertujuan agar remaja aktif dalam mengikuti kegiatan-kegiatan lain yang cakup dengan ajaran agama, supaya 
remaja bisa melakukankan aktivitas harian dengan ajaran Islam.

\section{Pembahasan}

Analisis Strategi dan Metode Dakwah dengan Manajemen Dakwah

Sebenarnya tujuan dakwah itu adalah tujuan diturunkan ajaran Islam bagi umat manusia itu sendiri, yaitu untuk membuat manusia memiliki kualitas akidah, ibadah, serta akhlak yang tinggi. Bisri Afandi (1984), mengatakan bahwa yang diharapkan oleh dakwah adalah terjadinya perubahan dalam diri manusia, baik kelakuan adil maupun actual, baik pribadi maupun keluarga masyarakat, way of thinkibg atau cara berpikirnya berubah, way of life atau cara hidupnya berubah menjadi lebih baik ditinjau dari segi kualitas maupun kuantitas. Yang dimaksudkan adalah nilai-nilai agama sedangkan kualitas adalah bahwa kebaikan yang bernilai agama itu semakin dimiliki banyak orang dalam segala situasi dan kondisi. Ketika merumuskan pengertian dakwah, Amrullah Ahmad (1983), menyinggung tujuan dakwah adalah untuk memengaruhi cara merasa, berpikir, bersikap, dan bertindak manusia ada dataran individual dan sosiokultural dalam rangka terwujudnya ajaran Islam dalam semua segi kehidupan.

Dalam bagian ini, penulis hendak menganalisis improvisasi strategi dakwah dan metode dakwah dikaitkan dengan fungsi-fungsi manajemen dakwah yang meliputi perencanaan, organisasi, dan strategi dakwah. Fungsi perencanaan dakwah pada perencanaan dakwah terkandung didalamnya mengenai hal-hal yang harus dikerjakan seperti apa yang harus dilakukan, kapan, di mana, dan bagaimana melaksanakannya.

Dalam melaksanakan da'wah di kafe yang pada dasarnya merupakan tempat berkumpulnya remaja, menggunakan pendekatan personal dan pendekatan partisipatif dengan demikian sasaran dakwah juga dilibatkan dalam perencanaan dakwah bahkan dalam penggalian permasalahan kegiatankegiatan dakwah, jika menginginkan hasil maksimal dan tepat sasaran sesuai tujuan akhir, maka pihak pemilik kafe sudah mempersiapkan rancangan sedemikian rupa pengajian dari jauh hari sebelum pelaksanaan kegiatan-kegiatan di mulai. Remaja dan masyarakat pengunjung kafe bambu, apabila ada informasi tentang kegiatan-kegiatan yang di laksanakan ada yang ikut bisa langsung datang ke kafe tersebut. Hal ini menjadi daya tarik sendiri bagi remaja dan masyrakat yang suka akan wawasan pengetahuan agama untuk lebih memperdalam pengetahuan keagamaannya melalui kegiatan-kegitan.

Kegiatan dakwah sejatinya bertujuan untuk menyebarkan ajaran agama Islam secara menyeluruh (Afandi :1984), dan rancangan kegiatan yang merupakan bagian dari mengfungsikan kafe tersebut untuk menyebarkan agama Islam aktivitas dakwah sebagai program pengembangan dakwah dari kegiatankegiatannya. Mengingat pengetahuan dan pemahaman agama zaman yang sudah semakin maju, maka aktivitas dakwah dapat digunakan sebagai alternatif dakwah. Kegiatan dakwah yang diadakan seperti pengajian remaja, ngaji bersama, bagi-bagi sembako dan sebagainya. Disamping itu terkadang mengundang 
narasumber untuk memberikan warna dakwah tersebut dan bahkan penulis terkadang diundang dan diminta untuk memberikan pengajian disana.

Kegiatan yang diadakan ini mendapat respon baik oleh masyarakat sekitar maupun remaja, mereka antusias dengan ikut serta mengikuti kegiatan yang di lakukan. Dengan diadakannya kegiatan tersebut diharapakan dapat mengetahui dan memahami keagamaan dan memperdalam. Karena bagaimanapun, kegiatan dakwah ini ditujukan untuk memenuhi dahaga spiritual akan hikmahhikmah religi. Para remaja dan masyarakat dapat mengambil i'tibar atau pelajaran dari kegiatan-kegiatan yang di lakukan seperti mengingatkan akan alam akhirat dimana segala amal perbuatan kita sewaktu di alam dunia akan dipertanggungjawabkan di hadapan Allah SWT, selain itu bertujuan agar remaja aktif dalam mengikuti kegiatan-kegiatan lain yang berkaitan dengan ajaran agama, supaya remaja bisa melakukankan aktivitas harian dengan ajaran Islam.

Improvisasi strategi dakwah yang dilakukan memuat fungsi perencanaan dakwah, karena strateginya sudah menyangkut merumuskan sasaran atau tujuan dakwah tersebut, menetapkan strategi menyeluruh untuk mencapai tujuan dan menyusun lengkap rencanarencana untuk mengintegrasikan dan mengkoordinasikan kegiatan-kegiatan. Strategi dakwah merupakan bagian dari perencanaan dakwah karena strategi dakwah termasuk pencapaian tujuan dakwah di kalangan remaja dan masyarakat atau sasaran dalam rangka pencapaian tujuan dakwah yang telah ditetapkan merupakan salah satu pembahasan terhadap proses perencanaan dakwah Islam, dan perencanaan dakwah merupakan salah satu fungsi manajemen dakwah. Manajemen seperti dikemukakan adalah mencakup kegiatan untuk mencapai tujuan. (Abdul Basit, 2013: 165).

Hal tersebut meliputi pengetahuan tentang apa yang harus mareka lakukan, menetapkan cara bagaimana melakukannya, memahami bagaimana meraka harus melakukannya dan mengukur efektivitas dari usaha-usaha mereka. Manajemen merupakan sebuah proses yang khas, yang terdiri dari tindakan-tindakan: perencanaan, pengorganisasian, menggerakkan, dan pengawasan, yang dilakukan untuk menentukan serta mencapai sasaransasaran yang telah ditetapkan melalui pemanfaatan sumber daya manusia serta sumber-sumber lain.

Dari penjelasan tersebut maka dapat dirumuskan bahwa manajemen dakwah adalah proses merencanakan tugas, mengelompokkan tugas, menghimpun, dan menempatkan tenagatenaga pelaksana dalam kelompokkelomok tugas dan kemudian menggerakkannya ke arah pencapaian tujuan dakwah. Dengan merujuk pada penjelasan di atas, maka jelaslah bahwa improvisasi strategi dakwah merupakan bagian dari manajemen dakwah, khususnya fungsi perencanaan dakwah dan lebihkhususnya lagi masuk dalam kategori penentuan dan perumusan sasaran dalam rangka pencapaian tujuan dakwah. Hasil-hasil yang diharapkan dapat dicapai oleh penyelenggaran dakwah dalam setiap tahapan, apakah itu hasil keseluruhan ataupun hasil dari 
masing-masing bidang, disebut sasaran atau target dakwah.

Dengan demikian sasaran dakwah itu adalah merupakan bagian dari tujuan dakwah. Ia adalah merupakan titik-titik tertentu dari hasil yang harus dicapai dalam setiap tahapan dalam rangka pencapaian tujuan dakwah yang telah ditentukan.

\section{KESIMPULAN}

Kesimpulan yang dapat dirumuskan berdasarkan deskripsi diatas yaitu:

Kegiatan pengembangan agama yang dilaksanakan bertujuan agar remaja dapat memahami ajaran agama dengan baik dan benar. Sehingga mampu mengembangkan ajaran Islam kepada masyarakat setempatnya. Improvisasi strategi dakwah yang dilakukan adalah melalui pendekatan personal dan pendekatan partisipatif serta metode pemberdayaan masyarakat yang meliputi pengembangan agama terhadap remaja dan pengembangan terhadap masyarakat.

\section{DAFTAR PUSTAKA}

Abdul Basit. (2013). Filsafat Dakwah. Jakarta: Rajawali Pers.

Affandi, Bisri. (1984). Beberapa Percikan Jalan Dakwah. Surabay : Fak Dakwah Surabaya

Ali Mohammad, Asrori Mohammad. (2009) Psikologi Remaja Perkembangan Peserta Didik. Jakarta : PT Bumi Aksara.

Amrullah, Achmad (editor). (1983).

Dakwah Islam dan

Perubahan

Sosial.

Jogjakarta : Primaduta

Arifianto \& Heru Dwi (skripsi). (2008). Strategi Dakwah Membangun Generasi Khaira Ummah Di Kampus Unissula, Semarang: IAIN Walisongo Fakultas Dakwah.

Arifin Anwar. (2011). Dakwah Kontemporer Sebuah Studi Komunikasi. Yogyakarta: Grama Ilmu.

Asmuni Syukir. (1983). Dasar-dasar Strategi Dakwah Islam, Surabaya.

Awaludin Pimay, (2005). Paradikma Dakwah Humanis., Semarang, Rasial.

Awaludin Pimay. (2005). Paradikma Dakwah Humanis Strategi dan Dakwah Prof. $\mathrm{KH}$. Saifuddin Zuhri, Semarang.

Azwar, Saifudin. (2001). Metode Penelitian. Yogyakarta: Pustaka Pelajar Offset.

Sofyan Rofi. (2018). Jurnal TARLIM "Pandangan Keluarga Petani Terhadap Pendidikan Anak (Studi Kasus Pada Orang Tua Siswa SMP Muhammadiyah 6 Wuluhan Jember) Hal 53-71. Jember : Universitas Muhammadiyah Jember 